\title{
RICO AND THE RUSSIAN MAFIA: TOWARD A NEW UNIVERSAL PRINCIPLE UNDER INTERNATIONAL LAW
}

\section{INTRODUCTION}

In 1994, East-West Invest (EWI), an American company, entered into a joint venture with Minutka Limited (Minutka Ltd.), a Russian company, to establish Subway fast-food franchises in Russia on behalf of Subway International.' The joint venture was established as Subway Limited Liability Company (Subway L.L.C.), with Minutka Ltd. contributing a leasehold to a dilapidated building in a prime St. Petersburg location, and EWI supplying all the financial support necessary for a Subway franchise. ${ }^{2}$

In December of 1994, the Subway shop opened its doors with Americans in senior management positions and Russians in junior management and staff positions. The joint venture turned out to be quite lucrative with all going well until May 1995, when the shop's American managers, Steve and Roberta Brown, took a vacation to Turkey. ${ }^{3}$ On June 2, Vadim Bordug, who controlled Minutka Ltd., claimed Brown had abandoned his post as manager, and Bordug took over complete control of the shop. ${ }^{4}$ The American partners were informed of the hostile take over, and were advised, to their dismay, that Bordug was part of the Tombovsky mafia group. ${ }^{5}$

The Americans immediately hired bodyguards for protection. Nevertheless, the Browns' lives were threatened, and Mr. Brown was

1. See Subway Sandwich Franchisee Has Had His Day in Court, Now What?, Russia \& Commonwealth Bus. L. ReP., May 7, 1997, Vol. 8, No. 3, available in LEXIS, Europe Library, RCBLR File [hereinafter Subway]. East-West Invest had acquired exclusive rights from Subway International to start Subway sandwich shops in Russia. See id. Subway had planned to immensely expand into Russia "starting with 30 restaurants in St. Petersburg over a five-year period." Eric Schwartz, Stockholm Favors Subway with \$1.2M Ruling, ST. Petersburg Times, April 7-13, 1997, (visited Jan. 22, 1998) <http://www.spb.su:8100 /times/251-252/stockholm.html >.

2. See Subway, supra note 1.

3. See id. By June of 1995, according to EWI, the St. Petersburg location was among "the top ten Subway stores in the world." Id.

4. See id. It was also at this same time that Vadim Bordug transferred $\$ 28,000$ from a "Subway ruble account" into an account where he had sole control, and another $\$ 70,000$ from a Subway account was transferred to a number of accounts in Ireland. Even though this money was returned to the bank from which it was taken, Subway officials claim Vadim Bordug was later able to take the funds again. See id.

5. See id. Vadim Bordug's account of the problems that have clouded the sandwich shop are much different than his American partners. He claims that the franchise agreement was never fair and that the Americans were deceptive about the entire franchise agreement. See Sarah Hurst, Partner Re-opens 'Subway,' ST. PETERSBuRg PRESS (visited Jan. 22, 1998) <http://www.spb.su:8100/sppress/121/partner.html > . It was because of these conflicts that he was forced to take action. See id. 
"beaten up" after a visit to the shop. 6 The United States Federal Bureau of Investigation (FBI) encouraged the American partners not to directly negotiate with the mafia group, and after a settlement could not be agreed upon, an arbitration award was entered on behalf of EWI by the International Arbitration Court in Stockholm for $\$ 1,200,000 .^{7}$ However, Bordug continued to operate the shop under the name of Minutka Ltd. ${ }^{8}$

Following his experiences, a spokesman for EWI has portrayed the Russian business climate as an environment where "[a]ll businesses in Russia are protected by one gang or another. They either pay protection money to the mafia or they hire licensed organizations staffed by former military people to keep the bad guys at bay. One way or another you pay money to people with guns." Unfortunately, the story of EWI's experience with a Russian criminal group is not new to those who have tried to tap the "free markets" of Russia.

A changing world environment has increased the globalization of world markets creating greater opportunities for criminal organizations to cross borders and function on a global level..$^{10}$ It is also possible that many powerful criminal groups, including La Cosa Nostra, have joined forces with other regional crime groups "form[ing] what Italian Judge Giovanni Falcone feared was a global organized crime network."11 The Chinese Triads,

6. See Subway, supra note 1. Vadim Bordug and his associates claim that there were never any threats made. See Hurst, supra note 5 . In fact, Bordug claims that it was the Americans who threatened him with hired mafia members. See id.

7. See Subway, supra note 1 . St. Petersburg has recently created its own international arbitrations court, hopefully making way for a firmer rule of law in business. See Schwartz, supra note 1.

8. See Eric Schwartz, Yakovlev Supports Subway Ruling, St. PETERSBURG TuMES, Apr. 28-May 4, 1978 (visited Jan. 22, 1998) <http://www.spb.ru/times/257-258/ yakovlev7.html >. St. Petersburg Governor Vladimir Yakovlev supported the arbitration ruling; nevertheless, his administration's involvement in its enforcement would not influence the substance of the judge's decision. See id.

9. Subway, supra note 1. EWI added that U.S. officials had urged him to "stay on the high road," and this actually caused more problems because "[i]t eliminated our ability to deal with them [Bordug's people] in the street." Id.

10. See The Threat From International Organized Crime and Global Terrorism: Hearings Before the House Comm. on Int'l Relations, 105th Cong. 53 (1997) (statement of Louis Freeh, Director, Federal Bureau of Investigation) [hereinafter Threat]. See generally CENTER FOR STRATEGIC AND INTERNATIONAL STUDIES (CSIS), GLOBAL ORGANIZED CRIME: THE NEw EMPIRE OF EVIL (Linnea P. Raine \& Frank J. Cilluffo eds., 1994) (transcriptions of speeches given at the Center for Strategic and International Studies (CSIS) conference on global organized crime held in Washington D.C., Sept. 26, 1994); UNDERSTANDING ORGANIZED CRMME IN GLOBAL PERSPECTIVE (Patrick J. Ryan \& George E. Rush eds., 1997) (collection of articles discussing global organized crime with commentary).

11. Sara Jankiewicz, Glasnost and the Growth of Global Organized Crime, 18 Hous. J. INT'L L. 215, 218 (1995). The international crime network was formed, according to Judge Falcone, "to avoid conflict, devise common strategy, and work the planet peaceably together." 
Japanese Yakusa, Columbian drug cartels, Turkish mafia and La Cosa Nostra are among the many powerful groups operating beyond their own borders; ${ }^{12}$ however, this note will examine only the Russian mafia. Specifically, this note will detail the problems criminal organizations present to governments that lack enforcement mechanisms against their reach and, most importantly, how these problems impact the world community.

Although the Russian mafia is one among many of the new criminal groups operating across borders, it has become one of the most powerful and feared regional crime groups in the world. ${ }^{13}$ In fact, of the estimated $\$ 351$ billion dollars that is annually transacted by Europe's mafia networks, "[t]he Russian mafia alone has a turnover of 200 billion dollars annually, making it . . the dominant economic force within Europe's organised crime [networks]."14

The establishment of Russian organized criminal groups as one of the leading threats to free-market reform in Russia and to other world markets has caused great concern from world leaders including those in the United States. ${ }^{15}$ Additionally, there has been increased apprehension throughout the world community caused by reports of Russian criminal groups allegedly stealing nuclear materials and selling them on the international black market to the highest bidder. ${ }^{16}$

Id.

12. See id. See generally Yiu-Kong Chu, International Triad Movements: The Threat of Chinese Organised Crime, CoNFLICT STUD., July-Aug. 1996 (summarizing the Chinese Triads).

13. See Jankiewicz, supra note 11 , at 218 . See also 140 CONG. REC. E1335-03 (daily ed. June 27, 1994) (statement of James Woolsey). In a statement presented to the U.S. House of Representatives, James Woolsey, former Director of the Central Intelligence Agency, asserted that "Russian organized crime is a unique subset of international organized crime [and] that [it] requires a special focus." Id. at E1335. Woolsey added that the normal devices nations use for international relations such as "diplomacy, demarches, hotlines, or summits" are not a possibility with criminal groups. Id.

14. Peer Meinert, Mafia Too Banks on Single European Currency and Globalisation, Sept. 2, 1997 (visited Nov. 6, 1997) <http://www.mpchronicle.com/daily/19970902/ $0209304 . \mathrm{html}>$. The past-reigning superpower of European organized crime, the Italian mafia, has only an estimated $\$ 50,000,000,000$ in annual business transactions. See id.

15. See generally Threat, supra note 10; Briefing on Crime and Corruption in Russia: Hearings Before the Senate Comm'n on Sec. and Cooperation in Eur., 103d Cong. (1994) (statements of Dr. Louise Shelley, Professor, American University and Stephen Handelman. Associate Fellow at the Harriman Center, Columbia University) [hereinafter Comm'n on Security].

16. See generally Security of Russian Nuclear Weapons: Hearing Before the House Subcomm. on Military Research \& Dev., 105th Cong. (1997) (statement of Rep. Curt Weldon) [hereinafter Weldon]. In his statement, Representative Weldon stated that Aleksandr Lebed, former Secretary of the Russian Security Council admitted, that terrorists may already be in possession of Russian nuclear weapons. See id. He also stated that Lebed had alleged that "84 suitcase-sized nuclear bombs" had been lost and that each of these could destroy 
The growing problem of global organized crime may create the need for more advanced legal mechanisms to attack the possibilities of increased cooperation among transnational groups. In the United States, a powerful weapon promulgated by Congress to combat organized crime is the Racketeer Influenced and Corrupt Organizations Act of 1970 (RICO). ${ }^{17}$ $\mathrm{RICO}$ has developed into a popular prosecutorial tool used to fight organized crime. It may be possible, with the cooperation of the world community through international treaties, to use similar measures to provide more than a mere monitor for those who are involved in organized crime and the corruption of world markets.

This note contends that the current problem of organized crime facing Russia actually extends beyond its own borders and requires immediate global attention by the world community. This note will first examine the mafia's role in Russia and the country's own inability to limit the effect the mafia has on the Russian people and the rest of the world. This note will next examine the use and ability of RICO to combat crime in the United States, followed by a brief discussion of the international legal principle of universal jurisdiction. Finally, this note will explore the possibility of implementing RICO-type standards on a global scale via the universal principle of international law.

\section{ORGANIZED CRIME IN RUSSIA AND THE COUNTRY'S EFFORTS TO CURTAIL ITS EFFECTS}

\section{A. Crime in Russia Under Soviet Rule}

Crime and the criminal underworld are not new to Russia. However, under Soviet rule, crime existed in a different scope and context than it does now under the free-market system. The primary purpose of the legal system in the former Soviet Union, as with other socialist regimes, was for "the protection of an economic system characterized by state ownership of the land." I8 In other words, the main purpose of criminal law was first to protect the Soviet regime and its property from activities that were outside

approximately 100,000 people. Id. See also 140 CoNG. REC. E1335-03 (daily ed. June 27, 1994) (statement of James Woolsey).

17. 18 U.S.C. $\$ \S 1961-1968$ (1994). RICO, however, is only one part of a powerful statute enacted to combat organized crime in the United States, that statute being the Organized Crime Control Act of 1970. See Organized Crime Control Act, Pub. L. No. 91-452, 84 Stat. 922 (1970).

18. Judith L. Anderson, Changing Conceptions of Economic Crime Under Russian Law, 14 WHITTIER L. REV. 451, 451 (1993). Economic crimes entailed many different types of activities from "private entrepreneurship or unauthorized foreign currency transactions . . . [to] overstating a factory's fulfillment of its plan or conduct intended to cope with deficits in the supply of goods and services." Id. at 452 (footnote omitted). 
the state-run system, and second to protect individual interests. In fact, economic crimes - those committed for personal profit - totaled approximately one third of all criminal convictions in the Soviet Union. ${ }^{19}$

Under Marxist and state theories, crime and law were to be eradicated in a true communist society after the role of the state withered away. ${ }^{20}$ To socialist planners, such as Karl Marx and Frederick Engels, crime was the result of a conflict in the attainment of goods based upon class struggles. ${ }^{21}$ So, in a true communist society, the struggle would end because society would provide for all citizens. However, the theory of communism that Marx and Engels created never developed in the Soviet Union, and the struggle for goods never ended.22 Rather, the struggle for goods and services resurfaced in the form of a black market. This black market was operated by criminals who were typically anti-communist leaders confined in the country's prison systems and who acted in cooperation with corrupt government officials. ${ }^{23}$

This connection between state officials and criminals appeared early in the development of the communist system. It began even before the October Revolution of 1917, and later, after the Soviet Union's power was established, those involved in the criminal underworld became enforcers and informers against political objectors found within the nation's prison system. ${ }^{24}$ Soviet citizens, despite evidence to the contrary, were always guaranteed by Soviet officials that organized crime could not survive in a socialist society. ${ }^{25}$ Yet, throughout the Soviet era, crime continued without

19. See id. The percentage of prisoners convicted of economic crimes remained steady throughout the Soviet era despite times of radical change. See id.

20. See generally R.W. MAKEPEACE, MARXIST IDEOLOGY AND SOVIET CRIMINAL, LAW (1980); KARL MARX \& FREDERICK ENGELS, THE COMMUNIST MANIFESTO (Frederick Engels ed., International Publishers 1948).

21. See Anderson, supra note 18, at 452 . See generally W.E. BuTLER, SOVIET LAW (2d ed. 1988). Once scarcity ends and a true Communist society is attained, there is no more need for the organization of the state to control daily activities. See id. at 30-40.

22. See Anderson, supra note 18 , at 452.

23. See generally Comm'n on Security (statement of Stephen Handelman), supra note 15. See also StEPHEN HANDElman, COMRADE CRIMINAL: RuSSiA's NEW MAFIYA 20-27 (1995). Handelman explains the power that laid behind the prison walls by stating:

[f]or decades, the prisons of the Soviet Union had been home to the world's most extraordinary criminal society. For almost a century, it had been known as vorovskoi mir, the Thieves World. From their cells, crime bosses planned and organized their operations across the country. No self-respecting gang leader ever needed to soil his hands by contact with the "civilian" world. Id. at 20.

24. See Shoshanah V. Asnis, Controlling the Russian Mafia: Russian Legal Confusion and U.S. Jurisdictional Power-Play, 11 CoNN. J. INT'L L. 299, 302 (1996). Even former Soviet leader, Joseph Stalin, in his early years, considered gang leaders among his closest confidants and later placed them into positions within his secret police. See id.

25. See HANDELMAN, supra note 23 , at 9 ; supra notes $18-22$ and accompanying text. 
much public discourse, and criminals were placed in Soviet prisons where they cooperated with corrupt state and prison officials allowing the black market to flourish. ${ }^{26}$

\section{B. Organized Crime in Russia Today}

\section{Crime During the End of the Soviet Empire}

By the mid-1980s, radical ideological reforms were instituted by Mikhail Gorbachev due to pressure by Western leaders, as a way of restructuring Soviet society to prepare for a new future. ${ }^{27}$ By the end of the Soviet era, a move toward capitalism had begun, but "the major sources of capital and wealth inside Russia were . . . black market money and money owned or manipulated or administered by the communist party." 28 Therefore, the profits that flowed from illegitimate means during the Soviet era were turned overnight into legitimate businesses, making it almost impossible for new entrepreneurs to compete with the criminal groups once major privatization began in 1991 and $1992 .{ }^{29}$ Leaders of criminal organizations, who once managed their gangs from behind prison walls, found it had become necessary and more profitable to do business out on the streets. ${ }^{30}$

After the fall of the Iron Curtain, the centrally-managed institutions previously installed to control crime and regulate the economy were not fully functional, and the carving up of the country's resources was left to corrupt state officials and criminal organizations who often operated cooperatively. ${ }^{31}$ Privatization, along with a lack of regulation, specific direction, or legitimate capital, provided a static environment ripe for the taking by criminals and

26. See HANDELMAN, supra note 23 , at 20 . Not only did the criminals influence the economy from their perch behind bars, but they also "altered the direction of their country's political development." Id. at 21. See also Jankiewicz, supra note 11, at 229.

27. See Jankiewicz, supra note 11 , at 226 . The reforms were stalled until 1988 due to problems associated with the Afghanistan war, and once installed, created new problems for Mikhail Gorbachev in the form of turmoil and struggles among the republics. See id. at 22627.

28. Comm'n on Security (statement of Stephen Handelman), supra note 15, at 13. Just before the Soviet Union's dismantling, the wealth of the black market "was estimated at 110 billion rubles ( 60.5 billion dollars at 1992 rates)." HANDELMAN, supra note 23 , at 28 . See also Louise Shelley, Post-Soviet Organized Crime and the Rule of Law, 28 J. MARSHALL L. REV, 827, 830 (1995).

29. See Asnis, supra note 24 , at 303 . The invitation of privatization into an economy is a major catalyst for "participation by organized crime due to the need for a large influx of capital, little of which is held by ordinary citizens." Shelley, supra note 28 , at 830 .

30. See HANDELMAN, supra note 23 , at 20.

31. See Comm'n on Security (statement of Stephen Handelman), supra note 15, at 9 . See also CSIS, supra note 10, at 107; Jankiewicz, supra note 11, at 229. 
corruption. $^{32}$ The criminal groups no longer needed to fear the KGB intervening in their attempts at international operations since the KGB's power was dismantled during the 1991 revolution and the new government provided little in its place. ${ }^{33}$

Without the proper mechanisms to control it following the 1991 revolution, crime "[became] the first post-Soviet growth industry" with Russia reporting a thirty-three percent increase in crime between the years of 1991 and $1992 . .^{34}$ It took very little time for the Russian mafia to infiltrate almost every aspect of post-Soviet life, including both legal and illegal markets. $^{35}$

\section{The Structure of Russian Organized Crime}

The traditional structure of a Russian criminal organization beginning at the time of the 1917 revolution was built upon the ideals of hierarchy and strict obedience to a "thieves" code. ${ }^{36}$ The members of these organizations were devoutly anti-communist and, for the most part, were required to lead modest, non-materialistic lives. ${ }^{37}$ However, as the Soviet era progressed and members of these criminal groups fell out of favor with group leaders for not abiding by the strict codes, new types of criminals and criminal organizations began to emerge that were sincerely concerned only with the accumulation of wealth and power. These individuals separated from the traditional Russian criminal groups and formed new gangs based on violence and materialism. ${ }^{38}$ These "new" criminal organizations that cooperated with

32. See Jankiewicz, supra note 11, at 230 . “[P]rivatization was for the Russian Mafia what Prohibition was for the Sicilian Mafia in America: a get rich quick scheme." Id.

33. See HANDELMAN, supra note 23 , at 29 . With the break down of the entire federal system at hand and the disappearance of law enforcement, criminals were allowed "freedom of movement that had been denied them under the police-state system." Id.

34. Id. at 3. See also Louis J. Freeh, Director of the Federal Bureau of Investigation (FBI), Speech at the Ministry of Internal Affairs Academy (July 4, 1994) (visited Sept. 23, 1997) <http:www.konanykhine.com/checkmate/freeh_mvd.htm> [hereinafter Speech] (explaining Russia's problems with organized crime and the United States' stance regarding those problems).

35. See Shelley, supra note 28 , at $828-29$. Compared to other organized criminal groups, Russian organized crime has expanded quickly because "[d]evelopments that have taken decades in other societies have occurred within a few years in the former Soviet Union." ld.

36. HandelmaN, supra note 23, at 28-34. See Office of Int'l Crim. Just., Russia: Organized Crime Old and New, 13 CRIME \& JUST. INT'L, Apr. 1997 (visited Sept. 3, 1997) <http://www.acsp.uic.edu/oicj/pubs/cjintl/1303/130310e.shtml > [hereinafter Office of ICJ].

37. See HANDElmaN, supra note 23 , at 37 . See id., at $13-43$, for a more detailed account of past Soviet criminal cultures.

38. See id. See also Victor Yasmann, Murder Incorporated, Russian Style, PRISM, Aug. 11, 1995 (visited Sept. 22, 1997) <http:// www.amber.ucsf.edu/ homes/ ross/ public_html/ 
corrupt government officials made the black market prosper. ${ }^{39}$

The actual structure of current Russian mafia groups has been hotly debated. The debate centers on whether Russian criminal groups are semiformal, hierarchial organizations, ${ }^{40}$ or individual criminals who band together in fluid groups occasionally using each other to perform a certain crime or scam. ${ }^{41}$ The latter conception resembles more the form of a gang culture, while the former suggests professional criminals.

Regardless of whether these are highly organized groups or bands of criminal gangs, a great distinction exists between the Russian mafia and other transnational criminal organizations: the criminal members' bond with those within the "power structure." 42 The criminal organizations operating within Russia today form an "unusual coalition of professional criminals, former members of the underground economy, [and] members of the former Party elite . . . def[ying] traditional conceptions of organized crime groups." 43 It is estimated that 8000 organized criminal groups, several hundred with international connections, existed in Russia in 1996, up from 3000 in 1992. ${ }^{44}$

The literature that has recently surfaced regarding the Russian mafia typically views these criminal organizations as posing the greatest threat internationally. ${ }^{45}$ Although most mafia groups increasingly function on a

russia_/ruscrime.txt > (detailing the waves of violence within post-Soviet Russia).

39. See HANDELMAN, supra note 23 , at 42.

40. See Office of ICJ, supra note 36.

41. See Peter Grinenko, Containing the New Criminal Nomenklatura, in GLoBAL Organized CRIME: THE NEW EMPIRE OF EVIL 111, 113 (Linnea P. Raine \& Frank J. Cilluffo eds., 1994).

42. Shelley, supra note 28 , at 829 . Shelley states that the danger posed by these groups is substantial because "[ $t$ ]hese are not individuals outside the power structure, but individuals representing a continuity from the old Communist power structure to the post-Soviet political arrangement. Once these individuals only had the use of state property. Now they have appropriated it and can send the proceeds outside the country." Id. See also J. Michael Waller \& Victor J. Yasmann, Russia's Great Criminal Revolution: The Role of the Security Services, in UNDERSTANDING ORgANIZEd CRIME IN GLOBAL PERSPECTIVE 187-200 (Patrick J. Ryan \& George E. Rush eds., 1997). See generally, Joseph L. Albini et al., Russian Organized Crime: Its History, Structure, and Function, in UNDERSTANDING ORGANIZED Crime In Global PERSPECTIVE 153-73 (Patrick J. Ryan \& George E. Rush eds., 1997).

43. Shelley, supra note 28, at 829-30. See generally 140 CONG. REC. E1335-03 (daily ed. June 27, 1994) (statement by James Woolsey); Threat, supra note 10; Jankiewicz, supra note 11, at 230-31; HANDELMAN, supra note 23.

44. See Phil Williams, Introduction: How Serious a Threat is Russian Organized Crime, reprinted in Russian ORGANIzed CRIME: THE NEW THREAT? 1, 11 (Phil Williams ed., 1997). FBI Director Louis Freeh stated in recent testimony before the House International Relations Committee that these groups included over 100,000 members. See Threat, supra note 10, at 6.

45. See generally Speech, supra note 34; 140 CONG. REC. E1335-03 (daily ed. June 27, 1994) (statement of James Woolsey); Weldon, supra note 16. The FBI, under the direction of Louis Freeh, opened its first branch office in Moscow in 1994 to help monitor the Russian 
global scale, they do not have the advantages that the Russian criminal groups have, such as their former military connections in European and African countries or their distinction as experts in economic crimes. ${ }^{46}$ The groups' ability to recruit from highly-trained, displaced military, intellegence, and security personnel also adds to the danger posed by the Russian criminal structure. ${ }^{47}$

\section{Current Russian Organized Crime Activity}

Like other organized crime groups throughout the world, Russian criminal groups have engaged in illegitimate businesses such as smuggling, prostitution, and other typical "rackets," while retaining a foothold in legitimate business as well. By 1995, Russian criminal organizations were believed to have "taken control [of] over $70-80 \%$ of all Russian commercial enterprises." 48 As privatization and capitalism were introduced, Russian criminal organizations, as well as foreign criminal organizations, found perfect opportunities to use their alliances with corrupt state officials to gain ownership or forge connections with legitimate businesses. It is estimated that Russian organized crime controls approximately 50,000 companies, those of which account for almost $40 \%$ of the Russian gross national product, ${ }^{49}$ and what businesses the mafia does not own legitimately, it controls illegitimately by strong-armed tactics involving the extortion of the most profitable businesses. ${ }^{50}$ Unlike criminal groups in other countries, the Russian mafia is essentially "inseparable from the Russian economy," 51 and

mafia's movements and provide assistance to Russian law enforcement. See Speech, supra note 34.

46. See Guy Dunn, Major Mafia Gangs in Russia, reprinted in RusSIAN ORGANIZED Crime: The New Threat? 63, 63 (Phil Williams ed., 1997). An estimated 110 Russian mafia gangs now function in more than 44 nations around the globe. See id. See also The Threat from Russian Organized Crime: Hearing Before the House Comm. on Int'l Relations, 104th Cong. 76 (1996) (prepared statement of Louise I. Shelley). “[S]pecialists from the security forces, military and large scale technical elite left unemployed or displaced by the collapse of the Soviet state . . . provide . . . computer and communication skills, technical expertise, and money laundering experience." Id. See generally HANDELMAN, supra note 23 , at 207-23.

47. See HANDELMAN, supra note 23 , at 222. See generally Waller \& Yasmann, supra note 42.

48. Alexandre Konanykhine \& Elena Gratcheva, Mafiocracy in Russia (visited Sept. 23, 1997) < http://www.konanykhine.com/mafiocracy.htm\#Government > .

49. See Dunn, supra note 46 , at 63.

50. See Konanykhine \& Gratcheva, supra note 48 . Methods of influence used by Russian criminal groups to gain power have included "kidnappings, assassinations, attacks on the family members [of enemies], [and] malicious persecution by corrupt government officials affiliated with the Mafia." Id.

51. Dunn, supra note 46, at 63 . See also Konanykhine \& Gratcheva, supra note 48; 
it is "practically impossible for a profitable business in Russia to avoid [being under the] control of the Mafia and regular extortion." \$2

Especially troubling to the Russian economy, as well as to the world economy, is Russian organized crime's involvement in the banking industry, money laundering, and other sophisticated economic frauds. ${ }^{53}$ Banking institutions have been overwhelmed with organized crime due to the slowly developing regulation, massive corruption, and sorely needed capital. ${ }^{54}$ Bank officials who do not play by the mafia's rules are threatened, kidnapped, or murdered, ${ }^{55}$ and business personnel in other industries have met similar fates. ${ }^{56}$ The ability to establish a bank in Russia with little capital "allows many questionable individuals to establish banking institutions." 57

Accompanying the global concern for Russia's lack of banking regulations is a growing interest in the amount of money laundering associated with Russia's corrupt banking institutions. These corrupt banks launder the money not only of Russian criminals but also of foreign criminal

Barbara Von Der Heydt, Corruption in Russia: No Democracy Without Morality (visited Sept. 23, 1997) <http://www.konanykhine.com/checkmate/heritage.htm>. Professor Louise Shelley contends that "[o]rganized crime exploits the legitimate economy while simultaneously limiting development of certain legitimate forms of investment and open markets that benefit a cross-section of the population." Shelley, supra note 28 , at 832 . This causes a problem because it requires the Russian economy to depend on illegal rather than legal economic activity. See id.

52. Konanykhine \& Gratcheva, supra note 48 . See also Shelley, supra note 28 , at 833. When a business is protected by an organized crime group, rather than by normal legal means, the business is vulnerable to extortion threats, providing a common problem for those in business who try to remain legitimate. See id. at 833-34.

53. See Shelley, supra note 28, at 829-31. See generally Stanley E. Morris, Maintaining the Security, Integrity, and Efficiency of Our Financial System in a Global Criminal Market, in GlOBAL ORGANIZED CRIME: THE NEW EMPIRE OF EVIL 60-70 (Linnea P. Raine \& Frank J. Cilluffo eds., 1994).

54. See Shelley, supra note 28 , at $830-32$. It has been estimated that more than half of Russia's 1747 banks are controlled by crime syndicates, and Western intelligence services report that these syndicates now "enjoy the protection of the ruling oligarchy that consolidated its power" at the time of Russian President Boris Yeltsin's 1996 illnesses. Arnaud de Borchgrave, Ignoring Russia's Crisis of Crime, WASH. TIMES, July 25, 1997, at A19.

55. See Konanykhine \& Gratcheva, supra note 48 . The banking industry appears to be the worst hit of businesses, but it is not the only one. "[D]uring the first ten months of 1994, 2,344 people were murdered" in Moscow alone, and this high rate has been attributed to a "large number of contract killings of business personnel." Shelley, supra note 28, at 833-34.

56. See Shelley, supra note 28 , at $833-34$. The media, since the revolution in 1991 , has received several threats and been involved in many acts of violence including the murders of several popular journalists. See Von Der Heydt, supra note 51. The murders were possible contract killings and the result of journalists trying to uncover corruption and crime. See id.

57. Shelley, supra note 28 , at 831 . A key feature to survival for the corrupt banks has been their connection "with politicians at all political levels." Id. This bond between the banks and politicians has severely weakened the emergence of democracy and free markets. See id. 
organizations as well. ${ }^{58}$ After the dirty money is laundered through the Russian banks, it is either reinvested in foreign banks or reintroduced into the economy as legitimate capital. ${ }^{59}$ By introducing laundered money into a national economy, the economic and political security of the nation is directly threatened because the nation's financial and political future becomes dependent on the rule of criminal oligarchies. ${ }^{60}$

Another criminal activity that has caused growing concern in Russia and throughout the rest of the world is the threat of nuclear material theft and diversion. In 1994, Louis Freeh, Director of the FBI, ${ }^{61}$ and R. James Woolsey, former Director of the United States Central Intelligence Agency (CIA) ${ }^{62}$ both recognized the problem as one for the entire world to monitor.

Even given the dangerousness of the Russian criminal groups and their ability to harness the country's economy, the more disturbing aspect of Russian criminal organizations is that they are "supplanting" the role of the state. ${ }^{63}$ Since the elimination of the Soviet Union as the key provider for society, the current governmental apparatus has been unable to provide for its citizens in many ways. Criminal groups within Russia now provide services that are typically delegated to other segments of a given society. These services include protecting businesses and employment while offering mediation in disputes between parties. ${ }^{64}$ Law enforcement, once furnished by the state, but now lacking official authority and effectiveness, is increasingly provided by organized crime groups in the form of private security to local neighborhood and regional districts. ${ }^{65}$

58. See Meinert, supra note 14. See also Shelley, supra note 28, at 831; Claire Sterling, Containing the New Criminal Nomenklatura, in GLOBAL ORGANIZED CRIME: THE NEW EMPIRE OF EVIL 106, 109 (Linnea P. Raine \& Frank J. Cilluffo eds., 1994). Claire Sterling, in her speech to the CSIS, stated that Russia is "perhaps the fastest growing money laundering center in the world with" money coming in from all over the world. Id.

59. See Pavel Ponomarev, Legal Measures Against Legalization of Criminal Assets as a Mean of Combatting Organized Crime, CJ Europe Online (visited Sept. 22, 1997) <http://www.acsp.uic.edu/OICJ/PUBS/CJE/060307.htm>.

60. See id. Legitimate activities have actually become the second largest business branch of global organized criminal groups with both the Russian mafia and La Cosa Nostra interested in the building sector, agricultural business, big trading chains, and finance and service industries. See Meinert, supra note 14.

61. See Speech, supra note 34. Representative Weldon, in his statement before Congress, asserted that "crime, corruption, incompetence, and institutional decay are so advanced in Russia that the theft of nuclear weapons, unthinkable in the Soviet war machine of the Cold War, seems entirely plausible in the Russia of today." Weldon, supra note 16.

62. See 140 CONG. REC. E1335-03 (daily ed. June 27, 1994) (statement of James Woolsey).

63. Shelley, supra note 28, at 834. See generally HANDELMAN, supra note 23; Comm'n on Security, supra note 15.

64. See Shelley, supra note 28, at 834. See also HANDELMAN, supra note 23, at 20-27.

65. See Shelley, supra note 28 , at 834 . It is estimated that " 100,000 private law enforcers presently operate without any regulation." Id. Alexander Gurov, director of a 
Citizens now also look to criminal groups for services previously provided by the courts, such as the enforcement of private contracts, debt collection and even some social services, to name a few. ${ }^{66}$ Russia's lack of stable democratic institutions, "[s]uch as a parliament, local government, the press, political parties, the church and labor unions," leaves the country "muscled aside by the enormous power wielded in Russia by organized crime and corruption." 67 For many Russians, nearly all aspects of their lives are influenced by organized crime. ${ }^{68}$

\section{Past Efforts to Control Organized Crime in Russia}

Russia has been left with an enormous problem of crime and corruption that, left unchecked, could at best lead to horrible foreign relations and at worst be the demise of the capitalist and democratic processes currently operating in Russia. ${ }^{69}$ Russian officials, in an effort to resolve their country's overall crime problems, have implemented several strategies toward reducing crime; however, these measures have taken years to implement and have met little success. The free-market infrastructure that was needed in the early stages after the 1991 revolution was held at bay by corrupt politicians and intense lobby groups. ${ }^{70}$ The lack of banking regulations, securities and trade market regulations, laws against money laundering, a criminal code specifically addressing organized crime, and other regulations, have only exacerbated the crime problem, leaving all who conduct business within Russian borders at the will of corruption and

security research institute at the Ministry of Security, asserts that corruption extends from the police through the courts and that where criminals in the past "tried to influence officials with bribes ... [they now] have their own lobby in the government and the parliament - not to mention the police and the prosecutor's office." Von Der Heydt, supra note 51.

66. See Mike Cormaney, RICO in Russia: Effective Control of Organized Crime or Another Empty Promise?, 7 TRANSNAT'L L. \& CONTEMP. PROBS. 261, 271-72 (1997). See also Shelley, supra note 28, at 834; Comm'n on Security (statement of Louise Shelley), supra note 15 , at 3 .

67. David Hoffman, Fragile Foundation, WASH. PosT, Dec. 26, 1996, available in WL 15124239.

68. See Comm'n on Security (statement of Lousie Shelley), supra note 15, at 6. With a near monopoly of intimidation and coercion, the mafia provides a relatively solid framework within which both legal and illegal activities take place. See Crime and Corruption in Russia and the New Independent States: Threats to Markets, Democracy and International Security: Before the House Int'l Affairs Comm. 103d Cong. (1996), available in LEXIS, News Library, Curnws File (prepared statement of Ariel Cohen, Senior Analyst, Heritage Foundation).

69. See generally Comm'n on Security, supra note 15 (detailing statements before congress detailing the problems Russia has faced since the rise of democracy and capitalism).

70. See Shelley, supra note 28, at 835 . See also Von Der Heydt, supra note 51; de Borchgrave, supra note 54. See generally Waller \& Yasmann, supra note 42 (describing the role of security services in the post-Soviet era). 
crime..$^{71}$

In early 1994, Russian President Boris Yeltsin, before the Russian Parliament, stated that "Russian organized crime represented 'the number one problem facing Russia'. [sic]"72 Yeltsin, in response to overwhelming public pressure to combat organized crime, issued a presidential decree in June 1994 which was specifically designed to control organized criminal groups and their spread of violence and corruption. ${ }^{73}$ In his decree, Yeltsin expressed his deep concerns by granting wide-ranging emergency authority to prosecutors and law enforcement officials, which allowed these officials to use Russian Army troops in order to conduct searches and detain suspects for up to thirty days while evidence was gathered for their trials. ${ }^{74}$ These measures reminded some of Joseph Stalin's oppressive police tactics and seemed to be an unconstitutional surveillance technique that would ultimately fail. ${ }^{75}$ Neither the Senate nor the Duma had the constitutional authority to reject or approve Yeltsin's presidential decrees ${ }^{76}$ therefore, the decree was considered law until the enactment of the Criminal Code of the Russian Federation in January of 1997 . This non-democratic move proved highly controversial, and many adamantly opposed the action. Nevertheless, the decree stood as law until 1997. ${ }^{77}$

71. See Shelley, supra note 28 , at 835 . The country's crime problems have allowed ultra-nationalist leaders such as, Vladimir Zhirinovsky, to gain support toward launching a "campaign to toughen up Russia's official attitude toward violent criminals . . . [by] 'set[ting] up courts on the spot to shoot the leaders of criminal bands.' " Asnis, supra note 24, at 309.

72. Konanykhine \& Gratcheva, supra note 48.

73. See Decree of the President of the Russian Federation No. 1226 of June 14, 1994, On the Urgent Measures to Protect the Population Against Gangsterism and Other Manifestations of Organized Crime, June 14, 1994, available in LEXIS, Intlaw Library, RFLAW File [hereinafter Urgent Measures]. See also Asnis, supra note 24, at 309.

74. See Urgent Measures, supra note 73, at 1 . The Presidential Decree, "aimed at the protection of the life, health and property interests of cititzens," was to be used only until the Russian Parliament adopted new laws that could address such problems. Victor Shabalin et al., The New Stage of the Fight Against Organized Crime in Russia, (visited Sept. 3, 1997) $<$ http://www.acsp.uic.edu/iasoc/newstage.htm >. In addition to the controversial searches and detention came inspections of financial activities and transactions of suspects and their family members. See id.

75. See Asnis, supra note 24 , at 312 . The decree caused great debate among lawyers, political scientists and the political elite. See Shabalin et al., supra note 74. Many thought that Russian President Boris Yeltsin's decree ran counter to the Constitution and violated the rights and liberties of Russian citizens. See id.

76. See Asnis, supra note 24, at 312. There are those who contest that the Decree was not a "war" against crime, but "was a war against wild democracy, wild capitalism. The actual mafiya lords, the godfathers of crime, were not touched. Particularly the Russian gangs, the Slavic gangs, who saw it as a way of getting rid of some of their rivals." Comm'n on Security (statement of Stephen Handelman), supra note 15, at 14.

77. See Asnis, supra note 24, at 312-13. Even though the Decree had its opponents, there were those who supported it and also those who did not think the Decree went far 


\section{Current Efforts to Control Crime}

Prior to the passage of the 1997 Criminal Code of the Russian Federation (CCRF) ${ }^{78}$ the controlling law on crime in Russia was the Soviet Criminal Code adopted in 1960, ${ }^{79}$ and President Yeltsin's 1994 decree on organized crime. Unfortunately, these tools did not readily provide any sort of real attack on organized crime. In 1996, the CCRF was passed supposedly providing the needed weapons to begin an offensive attack on Russia's crime problems. However, in reality, the CCRF may only be a source of frustration to courts and prosecutors who try to use it as a tool against organized criminal groups.

The main disadvantage of the CCRF is its inability to place any pressure on organized crime. Like most criminal codes, the CCRF's main focus is on individual crimes and the assignment of responsibility for an individual's involvement in those crimes. ${ }^{80}$ However, unlike the United States with its additional crime-fighting tools, such as RICO, the CCRF lacks substance when dealing with the true components of organized crime by failing to provide the ability to prosecute "large and diverse organizations." 81 Without recourse to the "criminal enterprise" component contained in RICOtype statutes, Russian prosecutors have been unable to hold members "liable for the crimes of other members of the organization unless they shared a specific common goal and agreement." ${ }^{82}$ As a result, prosecutors will be forced to adjudicate organized criminal groups by using conspiracy laws within the CCRF, and history has shown that this will likely be insufficient in dealing with organized criminal groups acting in Russia. ${ }^{83}$

enough. See Shabalin et al., supra note 74. Many well-known and respected lawyers supported the Decree believing that citizen's personal safety took precedence over their abstract civil liberties. The Liberal-Democratic Party (LDP) found the Decree too moderate and demanded army participation in the form of summary executions of criminal leaders and corrupt government officials. See id.

78. The Criminal Code of the Russian Federation, No. 64-FZ of June 13, 1996, available in LEXIS, Intlaw Library, Rflaw File (hereinafter CCRF).

79. See Harold J. Berman, Soviet Criminal Law and Procedure: The.RSFSR CODEs 141 (Harold J. Berman \& James W. Spindler trans., 1966); Criminal Code of the RSFSR (1961) (Soviet Criminal Code). Superceded only by amendments, the basic structure of the old Soviet code was left intact until the CCRF was adopted in 1996. See Anderson, supra note 18 , at 454.

80. See Cormaney, supra note 66, at 294.

81. Id. Even though the United States assisted Russian legislators with drafting many of the new provisions, problems will still persist due to prosecutors and law enforcement personnel lacking the needed experience of controlling crime through democratic means. See id. at $290,292$.

82. Id. at 294. See also infra notes $98-100$ and accompanying text.

83. See Cormaney, supra note 66, at 293-94. For a RICO-type standard, a prosecutor 
Even if the CCRF was a powerful tool capable of throwing a large net over the criminal groups that exist in Russia, it remains questionable whether the needed branches of law enforcement, such as the Russian police and courts, can effectively enforce and prosecute those who are active in the criminal underworld. ${ }^{84}$ Russian law enforcement, since the breakup of the Soviet Union, "has been powerless to solve the growing organized crime problem." 85 Corruption, in the form of bribery, is commonplace in major metropolitan areas, and those officers who are honest lack the technology and the funds to be efficient. ${ }^{86}$ The Russian court system is no better considering that the judges, prosecutors, and witnesses are frequent targets of bribes and threats. ${ }^{87}$

\section{Global Implications}

The result of Russia's organized crime problems is that Russia not only feels the effects of its evolving position as a safe-haven for crime and corruption. Several countries, particularly Germany and the United States, are recognizing a noticeable increase in Russian mafia activity within their borders. ${ }^{88}$ Criminal activities by organized criminal groups in Russia and throughout the rest of the world are affecting world markets and making international business difficult because legitimate enterprises are reluctant to begin investing in markets that are infiltrated with organized crime. ${ }^{89}$ FBI Director Louis Freeh, in his 1994 speech at the Russian Ministry of Internal Affairs Academy, warned that "[m]any businessmen are afraid of being kidnapped and held for ransom. I am afraid that, if unchecked, these organized crime groups and the terror that they generate will ultimately retard Russia's economic development and precipitate the flight of legitimate capital from your midst." 90

does not have to present evidence about "common agreements and intents," only "that a given person 'associated' with the group ... [and] manifest[ed] an agreement to participate." Id. at 294.

84. See generally id. at 305-311. According to one police inspector, "the law . . . punishes only those who lack imagination," and even though corruption has always been part of the police ethic, it is now increasingly widespread. Comm'n on Security, supra note 15, at 11 .

85. Jankiewicz, supra note 11 , at 250. See also HANDELMAN, supra note 23, at 20-27.

86. See Jankiewicz, supra note 11 , at 250 . It is estimated "that as much as ninety-five percent of the force is on the take." Id. In some Russian cities, "police are forced . . . to chase their suspects by taxi or on the bus." Comm'n on Security, supra note 15, at 11.

87. See HANDELMAN, supra note 23, at 24-25.

88. See Peter J. Vassalo, The New Ivan the Terrible: Problems in International Criminal Enforcement and the Specter of the Russian Mafia, 28 CASE W. RES. J. INT'L L. 173, 178-80 (1996).

89. See Speech, supra note 34.

90. Id. In October of 1997, Bernard Gilman, Chairman of the House International 
Another serious implication of Russian organized crime is the threatened diversion of nuclear materials and devices, along with the recruitment of Russia's elite nuclear scientists by terrorist groups. ${ }^{91}$ The mere possibility that terrorists may have acquired, diverted or stolen Russian nuclear weapons should be a matter of grave concern for the rest of the world. $^{92}$

\section{Legislative AND JUdiCIAL RESPONSE TO ORgANIZED CRIME IN THE UNTTED STATES}

During the 1960s, the United States faced its own organized crime problem. ${ }^{93}$ Congress found that organized crime was sufficiently distinguishable from individual crime and posed such a substantially greater threat to the welfare of the American economy and its citizens that it justified a categorically different legislative solution. ${ }^{94}$ Specifically, Congress desperately needed to confront criminal organizations' infiltration of generally legitimate businesses. ${ }^{95}$ Therefore, in order to control organized crime, Congress needed a new tool that could specifically deal with the group, or "enterprise" 96 feature of organized crime. Accordingly, RICO was enacted in 1970 to achieve those goals.

\section{A. Scope and Power of RICO}

\section{Overview and Features of RICO}

The general idea behind RICO is "to address the criminal organization

Relations Committee, in his opening remarks to the committee stated: "Organized crime groups, particularly in Russia, now have an almost complete choke-hold on the country's vast natural resources as well as the banks and media. Russia has been described as a kleptocracy from top-to-bottom, a semi-criminal state." Threat, supra note 10, at 49.

91. See Speech, supra note 34. In fact, Russian General Lebed, former National Security Advisor to Russian President Boris Yeltsin, "suggested that dozens of nuclear suitcase devices are mysteriously missing from Russia's military arsenal[,] . . . [a]nd the same threat exists from weapons using biological or chemical contents." Threat, supra note 10, at 50 .

92. See generally Weldon, supra note 16.

93. See Cormaney, supra note 66, at 277-79. 1986).

94. See Guide to RICO, Corporate Practice Series 4-5 (John C. Fricano ed.,

95. See id. at 5. Even though RICO was largely ignored for the first five years of its existence, it has become widely used by prosecutors in a vast array of prosecutions for organized crime, political corruption, white collar crimes and violent groups. See AMERICAN Bar Association, Criminal Justice Section, A Comprehensive PERSPECTIVE ON CiviL AND CRIMINAL RICO LegisLation AND LITIGATION 7 n. 17 (1985).

96. See 18 U.S.C. § 1961(4) (1994). 
as a whole instead of focusing liability only on its individual members." 97 Traditional criminal statutes focus on individuals and their responsibilities as does the CCFR. Typical criminal statutes provide prosecutors with substantial problems in convicting all, or even most, of the members who take part in a criminal organization. ${ }^{98}$ Therefore, traditional individualized criminal statutes leave the criminal organization intact, allowing the generally untouched leaders to continue committing crimes. ${ }^{99}$ By contrast, RICO provides prosecutors with the authorization to focus on the entire organization or "criminal enterprise" instead of just the individuals within it. ${ }^{100}$

However, RICO was not only designed as a tool to be used against organized crime infiltrating legitimate business; RICO was also to be used as a weapon against white collar crime and other forms of enterprise criminality. ${ }^{101}$ In addition to providing sanctions against criminal organizations, RICO also supplies remedies that allow both private parties and the government to bring suits in civil court. According to section 1964, the Attorney General or "[a]ny person injured in his business or property by reason of a violation of [section] 1962" can seek civil sanctions in either state or federal court. ${ }^{102}$ This important feature of RICO becomes very useful when law enforcement officials do not or cannot maintain an action against a criminal enterprise.

\section{How RICO Works}

The government in a criminal RICO action is required to prove that the defendant, "through the commission of two or more acts constituting a pattern of racketeering activity, directly or indirectly invested in, or maintained an interest in, or participated in, an enterprise, the activities of

97. Cormaney, supra note 66 , at 279.

98. See id. at $279-80$. In 1961 , the U.S. Supreme Court recognized the problems that organized criminal groups cause by stating:

[c]oncerted action both increases the likelihood that the criminal object will be successfully attained and decreases the probability that the individuals involved will depart from their path of criminality. Group association for criminal purposes often, if not normally, makes possible the attainment of ends more complex than those which one criminal could accomplish.

Callanan v. United States, 364 U.S. 587, 593 (1961).

99. See Cormaney, supra note 66 , at 280 . After the conviction of the low-level member, the untouched leaders can easily substitute another member into the convicted member's position. Id.

100. Id. The primary purpose of RICO is to "seek the eradication of organized crime in the United States . . . ." Organized Crime Control Act of 1970, Pub. L. No. 91-452, 84 Stat. 923 (1970).

101. See generally GUIDE To RICO, supra note 94, at 3-18.

102. 18 U.S.C. \$ 1964(c) (1994). 
which affected interstate or foreign commerce." ${ }^{103}$ Therefore, the government must prove each individual element: (1) the commission of two or more acts of "racketeering activity," (2) a pattern, (3) an enterprise, (4) an effect on interstate commerce, and (5) that the accused act is prohibited. ${ }^{104}$

First, a government indictment must assert that each act listed in the indictment is a "racketeering activity." 105 However, a RICO defendant does not need to be held responsible for each "activity" listed in section 1961. Instead, the defendant may be charged with violating one or all of the activities listed. Nevertheless, a RICO charge does require that the defendant be responsible for a minimum of two acts as set forth in section 1961 before a RICO violation is "chargeable." 106

Second, RICO further requires that these two predicate acts constitute a pattern of racketeering activity. ${ }^{107}$ A "pattern of racketeering activity" is defined as "at least two acts of racketeering activity, one of which occurred after the effective date of this chapter and the last . . . occur[ing] within ten years . . . after the commission of a prior act of racketeering activity." 108 Courts have struggled with whether to interpret this element broadly or narrowly, making it one of the most controversial aspects of the RICO statute. ${ }^{109}$ One of the leading cases which tried to clarify congressional intent on the meaning of a "pattern of racketeering activity" was Sedima, S.P.R.L. v. Imrex Co, Inc. ${ }^{110}$ After examing RICO's congressional history, the Supreme Court discussed in Sedima that RICO, even in a civil proceeding, is designed to remedy organized crime, not isolated offenses. ${ }^{11}$ " Therefore, isolated acts do not constitute a pattern; a pattern consists of "continuity plus relationship." 112

Third, RICO requires that a person, as defined by the statute, must

103. Lance Bremer et al., Racketeer Influenced and Corrupt Organizations, 34 АM. CRIM. L. REV. 931, 935 (1997).

104. See id.

105. 18 U.S.C. \$ 1961 (1994).

106. See id. RICO extends the "racketeering activity" definition over a large assortment of indictable federal and state crimes. See 18 U.S.C. 1961(1)(A)-(E) (1994).

107. See Bremer et al., supra note 103, at 937.

108. 18 U.S.C. §1961(5).

109. See Bremer et al., supra note 103 , at 935.

110. Sedima, S.P.R.L. v. Imrex Co., Inc., 473 U.S. 479 (1985).

111. See id. at $495-97 \&$ n.14. It should be noted that most of the court's discussion regarding "pattern" took place as dictum in a footnote. The Sedima court also found that it was not necessary to establish that the defendant had a prior conviction in order to establish "racketeering activity." Id. at 496. Therefore, there is not a prior conviction rule for a RICO proceeding. Id.

112. Id. at 497 (quoting S.REP. No. 91-617, at 4). Once a person commits two predicate acts that are "related" and "pose a threat of continued criminal activity," a substantial argument has been made to sustain RICO liability. See H.J. Inc. v. Northwestern Bell, 492 U.S. 229, 239 (1989). 
"directly or indirectly acquire interests in, or administer, an "enterprise'" which includes individuals, partnerships, corporations, associations, or other legal entities, and "any union or group of individuals associated in fact although not a legal entity." 113 The "enterprise" element has also been the subject of great controversy with courts using large amounts of discretion in their development of the law concerning "enterprise."114

Fourth, the "racketeering activity" must have had some effect on interstate commerce. Even though "[c]ourts initially held that the enterprise itself, and not the predicate acts, must affect interstate commerce[,] . . . many courts now exercise jurisdiction when the predicate acts form a nexus with the interstate commerce. ${ }^{n 115}$ There is a nexus with interstate commerce "as long as interstate commerce is affected by either the enterprise or its 'activities." "116

Finally, the last element necessary to complete an action for violation of RICO is that the activities must be prohibited pursuant to section 1962. The activities included in section 1962 are as follows: “(1) investing income from a pattern of racketeering activity; (2) acquiring or maintaining an interest in an enterprise through a pattem of racketeering activity; (3) conducting the affairs of an enterprise through a pattern of racketeering activity; and (4) conspiring to do any of the above." 117

Once a conviction is obtained, RICO provides three different types of penalties for violators. Violators can be fined or imprisoned for up to twenty years, as well as subjected to mandatory asset forfeiture. ${ }^{118}$ These sanctions give the government authority to attack the economic bases of racketeering activities. Much of the success of RICO can be directly tied to its harsh penalties, since the penalty for a RICO violation is significantly more severe than the penalty for the commission of one of its predicate offenses. ${ }^{119}$ It is the prosecution's use of the criminal forfeiture feature that poses the greatest threat to a criminal organization. ${ }^{20}$ Forfeiture removes the potential illegal profit from activities engaged in by organized crime groups and places the generated revenue from the forfeiture actions into a fund to further enhance law enforcement and compensate victims. ${ }^{121}$

113. Bremer et al., supra note 103, at 942 (footnotes omitted).

114. Id. at 943

115. Id. at 949 .

116. Id.

117. Id. at 950 (footnotes omitted).

118. See 18 U.S.C. $§ 1963$ (a) (1994).

119. See Cormaney, supra note 66 , at $288-89$.

120. See id.

121. See id. at 289. Criminal forfeiture actions are actually quite rare due to their controversial nature and have been attacked by defendants on constitutional grounds. Constitutional arguments have been based both on the "Eighth Amendment prohibition of cruel and unusual punishment" and arguments for Due Process rights of third parties. Id. at n.170. 


\section{Benefits of RICO}

The success of RICO in the United States is a result of its extremely broad and flexible language and the courts' cooperative interpretations. ${ }^{122}$ The drafters of RICO intended to define organized crime loosely in order to "deliberately cast the net of liability wide . . . to avoid open loopholes through which the minions of organized crime might crawl to freedom." 123

In fact, Congress included within the statute a liberal construction clause that provides "the provisions of this title shall be liberally construed to effectuate its remedial purposes." 124

In line with this liberal legislative intent has been a very broad and liberal application by U.S. courts. In United States v. Turkette, the Supreme Court stated that "the most reliable evidence of congressional intent is found in the language of the statute."125 The courts' application of the broad statutory language has allowed RICO actions to be used against a number of different types of criminal enterprises rather than just the traditional members of organized crime. For example, RICO can be, and has been, used in various forms of litigation, from cases involving complex white color crime schemes and political corruption to traditional types of organized crime..$^{126}$

However, even though courts agree that RICO is to be given very broad application, its use remains questionable in extraterritorial litigation for violations that reach beyond the borders of the United States or violations that are committed by foreign parties. As a matter of international comity and sovereignty, the conventional consensus in applying federal statutes is that they are to be limited to acts that take place within the United States. ${ }^{127}$ However, if Congress "clearly indicates an intent to the contrary" within the statute or legislative history, a court may find that extraterritorial application

122. See id. at 285-86.

123. Sutliff, Inc. v. Donovan Companies, Inc., 727 F.2d 648, 654 (7th Cir. 1984), quoted in Cormaney, supra note 66, at 285.

124. Organized Crime Control Act of 1970, Pub. L. No. $91-452,84$ Stat. 947 (1970).

125. U.S. v. Turkette, 452 U.S. 576, 586 (1981). The U.S. Supreme Court has stated that "RICO is to be read broadly. This is the lesson not only of Congress' self-consciously expansive language and overall approach . . . , but also of its express admonition that RICO is to "be liberally construed to effectuate its remedial purposes." Sedima, S.P.R.L. v. Imrex Co., Inc., 473 U.S. 479, 497-98 (1985) (quoting the Organized Crime Control Act of 1970).

126. See, e.g., United States v. Brooklier, 685 F.2d 1208 (9th Cir. 1982), cert. denied, 459 U.S. 1206 (1983) (involving RICO prosecution of members of La Cosa Nostra, a criminal enterprise involved in a wide range of racketeering activities, including murder, extortion, gambling and loansharking); United States v. Mandel, 431 F. Supp. 90 (D. Md. 1977) (convicting a Maryland governor for RICO mail fraud and bribery); United States v. Tamura, 694 F.2d 591 (9th Cir. 1982) (upholding conviction of corporate representative for RICO mail and wire fraud and bribery).

127. See Lawrence W. Newman and Michael Burrows, Extraterritorial Application of RICO in the Second Circuit, N.Y. L. J., Jan. 30, 1997, at 3. 
is permissible. ${ }^{128}$ Therefore, even though RICO does not include specific language regarding its application extraterritorially to foreign defendants, this fact does not automatically preclude RICO litigation for the acts of foreigners. ${ }^{129}$ Two federal circuits, the Second ${ }^{130}$ and Ninth, ${ }^{131}$ have specifically handled the extraterritorial jurisdiction question posed by RICO litigation; yet no consensus has been reached as to its extraterritorial application. ${ }^{132}$ Even if available extraterritorially, RICO's use against international actors in U.S. courts would probably be limited to acts that form a nexus with the United States due to considerations of international comity and sovereignty. ${ }^{133}$

Although RICO is most often viewed from a criminal perspective, its success in controlling organized crime is not limited to criminal sanctions alone; a criminal organization can be held liable in civil actions as well. RICO states that "[a]ny person injured in his business or property by reason of a violation of section 1962 . . . may sue therefor . . . and shall recover threefold the damages he sustains and the cost of the suit, including a reasonable attorney's fee." ${ }^{134}$ Civil actions are available to both private citizens and the government, and since neither the states nor the federal govenment have the resources to prosecute every organized crime group, civil actions have become a very useful tool when used by prosecutors and private parties. ${ }^{135}$

Possibly the greatest benefit that RICO offers in combatting organized crime is the concept of "criminal enterprise." Traditionally, conspiracy law could not be used in actions against criminal organizations because in typical organized criminal groups there were several diverse types of conspiracies but "no . . . commonly shared criminal objective." ${ }^{136}$ Thus, the group could be prosecuted only for several small conspiracies instead of one large conspiracy because the members typically lacked any kind of shared agreement. ${ }^{137}$ RICO solved the problem by introducing the concept of "enterprise conspiracy." 138 For a RICO prosecution, it is the agreement to participate in the affairs of a criminal enterprise by committing two acts of

128. Id.

129. See id.

130. See Alfadda v. Fenn, 935 F.2d 475 (2d Cir. 1991) (adopting a "conduct" test where the harmful act took place in the United States).

131. See Butte Mining, PLC v. Smith, 76 F.3d 287 (9th Cir. 1996).

132. See Newman \& Burrows, supra note 127 , at 3.

133. The ability of RICO to be used in an extraterritorial sense as a possible standard for universal jurisdiction is explained in infra Part V.

134. 18 U.S.C. $\$ 1964$ (c) (1994).

135. See Cormaney, supra note 66 , at $288-90$.

136. Id. at 283.

137. See id. at 283-84.

138. Id. at 284. 
racketeering activity to further the goals of the enterprise which forms the crime. Neither the prosecutor nor the private plaintiff need prove that the defendant knew about the activities of other members nor that there were many diverse types of criminal activity. Liability, for civil suits, or a conviction, for criminal prosecutions, will attach when it is shown "that each [defendant] 'associated' with the criminal enterprise by performing two acts of racketeering activity ...., "thus allowing all of the members of the organization to sustain liability for the crimes of the organization. ${ }^{139}$ This new feature "allow[s] ... [for] criminal organization[s] to be tried as a whole, and not merely as the sum of its diverse parts." ${ }^{140}$ Therefore, a RICO indictment is not limited to the requirements of traditional conspiracy law where a common criminal objective and an agreement is needed for each act. $^{141}$

B. Why RICO-Type Legislation Implemented in RUSSIA Would Currently be Futile

The problems that confront Russia and other nations regarding organized crime could possibly be addressed by implementing several of the successful components of the United States' RICO Act. ${ }^{142}$ The CCRF could be amended by Parliament to provide for the broader and more flexible standards of RICO. However, the largest obstacle to the effective addition of RICO-like provisions to the CCRF is not substantive law, but a lack of democratic and free-market legal traditions and the slow development of civil society. Interestingly, this development has been impeded by organized crime. These problems would overshadow the legislation to the point that organized criminal groups could be neither effectively prosecuted nor successfully sued.

\section{Organized Crime has Influenced Virtually Every Aspect of Russian Society}

By 1994, it was evident that Russian organized crime had a foothold in most institutions and industries within the country. The perception of the power of organized crime among citizens of Russia was made all too clear in a poll in March of 1994, where in response to the question "Who controls Russia?," 23\% responded "the Mafia."143

139. Id.

140. Id.

141. See id. at 283.

142. See id. at 290.

143. 140 CONG. REC. E1335-03, E1336 (daily ed. June 27, 1994) (statement of James Woolsey). Only $14 \%$ of those responding to the survey answered "President Yeltsin." See id. 
Street-level criminal groups are not the only segments of Russian society that are being accused of operating as criminal organizations. In 1993, the Vice President of Russia, Alexander Rutskoy, presented a report to the Supreme Soviet that accused virtually all principal members of President Boris Yeltsin's cabinet of corruption. The Supreme Soviet responded by demanding the resignation of those officials and commanded Prosecutor General Stepankov and Minister of Security Barannikov to criminally prosecute the named members. ${ }^{144}$ To counter the Supreme Soviet's command, Yeltsin hurriedly dismissed Vice President Rutskoy, Prosecutor General Stepankov, and Minister of Security Barannikov accusing them of corruption. ${ }^{145}$

In Russia today, the political reality practically excludes the possibility of non-corrupt government officials. Bribing organized criminal groups is a typical "prerequisite to all 'attractive' government appointments both on local and on national level[s]." 146 Dr. Louis Shelley, Co-Editor-in-Chief of the Journal of Post-Soviet Democratization (Demokratizatsiya) and professor at American University, has warned that:

[t]he impact of corrupt legislators is particularly important at this crucial stage where legislation that will govern the country in subsequent decades is now being implemented. Once the basic framework is enacted, vested bureaucratic and financial interests combined with inertia will make it difficult to implement fundamental change. ${ }^{147}$

Organized crime is assisting the rise of regional powers in Russia, where the rise of local fiefdoms, protected by loyal armed bands, seeks political and economic control over their regions. ${ }^{148}$ These local leaders may enjoy more power than in the Soviet period because they own, rather than control, property and because the "law enforcers" are employed by them rather than the state. ${ }^{149}$ Therefore, even if RICO-type legislation were to be implemented, it will be substantially difficult for Russia to enforce, let alone to bring action against, powerful organized criminal groups.

144. See Konanykhine \& Gratcheva, supra note 48.

145. See id.

146. Id.

147. Shelley, supra note 28 , at 835 . Keeping in mind that an estimated $25-30 \%$ of Russian parliament members have some connection to the mafia, it is important to note that the Russian parliament has granted itself immunity through legislation, thereby creating an added incentive for criminals to form a nexus with those in power or become elected officials themselves. See id.

148. See id.

149. See id. 


\section{Weak Commitment to Democratic and Legal Principles}

A notable Russian writer, Nobel Prize-winner Alexander Solzhenitsyn, wrote in November of 1996 that "Russia has no semblance of democracy and is far from real market reform . . . . A stable and tight oligarchy of 150-200 people is deciding the fate of the nation . . . [where] nearly criminal reforms ... have created a new class of mafia capitalists." 150

The lack of governmental leadership and corruption in both the past and current governmental structure has led to public frustration, disillusionment, and a lack of commitment to democratic and free-market reforms. In addition, organized crime has transformed public opinion about the new societal structure. ${ }^{151}$ There is a disrespect and disregard for authority and the law. A government official summarized the problem by stating, "[s]ome of our people seem to understand democracy as being able to do whatever they want .... As a result, ... we have wild democracy, an epidemic of seizing everything in sight, of getting rich at any cost."152

\section{The UNIVERSAL PRINCIPLE OF INTERNATIONAL LAW}

\section{A. Principles of International Law}

According to international law, a state must assess its jurisdictional authority to appropriately punish criminal acts that also affect the interests of any other state. ${ }^{153}$ The anticipated jurisdiction of one nation must be balanced with the interests of other nations in regard to any particular criminal act. ${ }^{154}$ International law has developed well-settled principles to determine if a state may apprehend, prosecute, and punish those acts that extend beyond domestic borders. ${ }^{155}$ These jurisdictional principles of international law have been established in order to encourage harmony among foreign states by seeking to avoid or settle controversial assertions of jurisdictional authority. ${ }^{156}$ Therefore, under the principles of international law, a state is forbidden from exercising its authority unless it has jurisdiction to prescribe its authority over the criminal acts in question. ${ }^{157}$

150. Konanykhine \& Gratcheva, supra note 48.

151. See Comm'n on Security (statement of Louise Shelley), supra note 15, at 2-3.

152. HANDELMAN, supra note 23, at 4 (quoting Aslambek Aslakhanov, former Director of Supreme Soviet Parliamentary Committee on Law and Order).

153. See Kenneth C. Randall, Universal Jurisdiction Under International Law, 66 TEX. L. REV. 785, 785 (1988). For the remainder of this note, the term "state" refers to a country or nation-state.

154. See id. at 786.

155. See id. at 785 .

156. See id. at 786.

157. See Eric S. Kobrick, The Ex Post Facto Prohibition and the Exercise of Universal 
A state may gain criminal jurisdiction over an offense pursuant to international law in one of five ways: ${ }^{158}$ (1) under the territorial principle jurisdictional authority based on where the alleged crime actually was committed including "objective" territorial jurisdiction, or the "effects" doctrine. The "effects" doctrine permits countries to exercise authority over "acts committed outside territorial limits but intended to produce, and producing, detrimental effects within a nation"; (2) nationality principle jurisdictional authority on the grounds that the accused is a citizen of the prosecuting state; (3) passive personality principle - jurisdictional authority based on the fact that the victim is a national of the prosecuting state; (4) protective principle - jurisdictional authority due to the fact that the act threatened the security, integrity or "a basic governmental function" of the prosecuting state; and (5) universality principle - jurisdictional authority for crimes recognized by the world community as so offensive that the "traditional nexus with either the crime, the alleged offender, or the victim" is not needed. ${ }^{159}$ It is this last principle of international jurisdiction that will be the primary focus of the remainder of this note.

Universal jurisdiction allows a state to maintain extraterritorial jurisdiction over a foreigner who has been involved in an "universally condemned crime." 160 Unlike the other principles of international jurisdiction which require that there be some nexus between the prosecuting state and the act, the universality principle is based on the theory that every state has an interest in exercising its authority over acts that "threat[en] . . . the well-being of the international community." ${ }^{161}$ Universal jurisdiction can be established solely by acquiring custody of the alleged offender within the boundaries of the prosecuting state. ${ }^{162}$

The basic rationale supporting the universality principle is that certain crimes "are so universally condemned that the perpetrators are the enemies of all people." 163 Since certain types of crimes can "undermine the very foundations of the enlightened international community as a whole and . . . jeopardize the security of all nations," the nexus requirement for jurisdiction is inferred and expanded to include all states. ${ }^{164}$ Therefore, an act that is specified as universally offensive creates criminal liability for the individual

Jurisdiction Over International Crimes, 87 COLUM. L. REV. 1515, 1518 (1987).

158. See Kobrick, supra note 157 , at 1519.

159. Id.

160. Christina E. Sorensen, Drug Trafficking on the High Seas: A Move Toward Universal Jurisdiction Under International Law, 4 EMORY INT'L L. REV. 207, 219 (1990).

161. Randall, supra note at 153, at 790 (quoting United States v. Layton, 509 F. Supp. 212, 223 (N.D. Cal.), appeal dismissed, 645 F.2d 681 (9th Cir.), cert. denied, 452 U.S. 972 (1981)).

162. See Kobrick, supra note at 157 , at 1519.

163. Id. at 1520 (quoting Demjanjuk v. Petrovsky, 776 F.2d 571, 582 (6th Cir. 1985)).

164. Id. 
wherever he may go. ${ }^{165}$

However, not all crimes are universally condemned. In fact, there are only a limited few that have been specified as granting universal jurisdiction. These international crimes have been assigned universal jurisdiction in basically two ways: (1) through customary international law and; (2) by multilateral conventions and treaties specifying the rights and obligations of states. ${ }^{166}$

\section{B. Universal Jurisdiction by Custom or by International Agreement}

\section{Customary Universal Jurisdiction}

International law, through customary means, occurs "from a general and consistent practice of states followed by them from a sense of legal obligation." 167 Exactly when a practice has matured to custom has been the source of much controversy, and though a custom does not require that every state follow it, there must be general acceptance. ${ }^{168}$ Therefore, to establish a custom, a majority of states must deem the act criminal and demonstrate this by some form of consistent practice. ${ }^{169}$

The initial universal crime that was established by way of custom was the criminal act of piracy. ${ }^{170}$ Any state that seized a pirate ship, or ship taken by piracy and under piratical control, could perform the necessary arrests and seize the ship's property. ${ }^{171}$ The state that performed these acts of arrest and seizure could impose its own penalties with regard to the offenders and the ship..$^{17}$ In the modern world, the punishment of piracy has been codified into international agreements that stipulate the rights and obligations of nations in the pursuit of pirates. ${ }^{173}$

165. See id.

166. See id. at n.46. See also Statute of the International Court of Justice, art. 38, June 26, 1945, 59 Stat. 1055, T.S. No. 993.

167. RESTATEMENT OF THE LAW, FOREIGN RELATIONS LAW OF THE UNITED STATES (REVISED) § 102(2) (Tentative Draft No. 1, 1980).

168. See Kobrick, supra note 157 , at n.46.

169. See id. at 1529.

170. See Randall, supra note 153 , at 791 .

171. See id. at 792 .

172. See id. at 792. The penalties imposed on the ship were, however, still "subject to the rights of third parties acting in good faith." Id.

173. See, e.g., 1982 United Nations Convention on the Law of the Sea, Dec. 10, 1982, art. 105, reprinted in The Law of the Sea, U.N. Doc. A/Conf. 62/122, U.N. Sales No. E.83.V.5 (1983). The United States did not sign the 1982 Convention, but was a party to the 1958 Convention. 


\section{Universal Jurisdiction by International Agreement}

The universality principle has expanded throughout history to include several other crimes. Currently, international agreements, and not custom, are the primary source of international law, creating obligations and rights for those nations that are parties to the agreements. ${ }^{174}$ However, since several nations have implemented international agreements condemning or stating policy on certain crimes, and while the agreements gain widespread acceptance from nonparties, it is possible for these agreements to become a matter of customary law. ${ }^{i 75}$ International crimes that have been given universal jurisdiction to some extent by means of custom or international agreement are as follows: piracy, crimes of war, genocide, terrorism, slave trading, hijacking and sabotage of aircraft, hostage taking, crimes against internationally protected persons, apartheid and torture. ${ }^{176}$ However, since international law consists of "the action of governments designed to meet a change in circumstances[, i]t grows, as did the Common-law, through decisions reached from time to time in adapting settled principles to new situations. ${ }^{17}$ Therefore, the world community continues to have discretion to determine that other types of behavior are within the scope of universal jurisdiction.

\section{The APPlicability of RICO as a Global DEFENSE MEChanisM AGAINST RUSSIAN ORGANIZED CRIME AND OTHER TRANSNATIONAL ORGANIZED CRIME GROUPS}

The recent threat of transnational organized crime presented to the United States, Russia, and the rest of the world is real. ${ }^{178}$ By using diverse

174. See Kobrick, supra note 157 , at n.46.

175. See id.

176. See Randall, supra note 153 , at $788-89$.

177. Kobrick, supra note 157, at n.100 (quoting Jusice Jackson, chief American prosecutor at Nuremberg).

178. Chairman A. Benjamin Gilman, addressing the United States House International Relations Committee on October 1, 1997, forewarned his audience of the following:

I will humbly suggest that what we are witnessing these days are three types of criminal activities: Drugs, terrorism and organized crime, which are like three huge geological plates, which are slowly starting to shift and grind together. They could, ultimately, produce an earthquake of unprecedented magnitude and destruction . . . . What all of this tells us is that in the interest of global business, these groups will soon cross a threshold of compartmentalization, will begin merging and are working jointly with one another. This new globalized crime wave will take advantage of the new technologies to hide their activities, and when combined with their ability to move huge sums of money instantly, actually threaten every free society's ability to assert financial control over its own economy. 
groups, a criminal organization can carry out complex frauds, violent crime, and societal change without fear of reprisal for a great majority of the group's members, especially the group leaders, if the country where the crime is conducted is far removed from the country that is affected. As international commerce expands, so do organized criminal groups, among which the possiblity to control vast amounts of capital and property illegally, fueled by a lack of governmental control, provide unprecedented power which should strike a nerve in world leaders. ${ }^{179}$ Allowing criminal groups to gain power in nations with weak infrastructures promotes wide use of "racketeering activity" as a viable social apparatus.

It is evident from the scope of Russia's organized crime problems that new, creative enforcement mechanisms must be devised to control widespread, international criminal organizations. ${ }^{180}$ A mechanism that could be installed for combatting Russian organized crime and other transnational groups is a policy of universal jurisdiction over criminal enterprises that engage in racketeering activity, with adjudication and enforcement based on a RICO-type standard. However, granting universal jurisdiction over criminal enterprises would require official recognition by the international community similar to that of piracy and other universally condemned crimes. Therefore, it may prove useful to compare the acts performed by criminal organizations to the crime of piracy in order to determine whether criminal enterprises could be viewed as universally condemned crimes.

\section{A. Comparison of Piracy and Criminal Organizations}

The act of piracy was granted universal jurisdiction for several reasons, but the most accurate rationale supporting universal jurisdiction for acts of piracy is that they pose an international threat to an interest held by all states

Threat, supra note 10.

179. See id. See generally, 140 CONG. REC. E1335-03 (daily ed. June 27, 1994) (statement of James Woolsey) (describing the impact of the Russian mafia on national and world security); Threat, supra note 10, at 1-3.

180. See Threat (statement of Chairman Bernard Gilman), supra note 10, at 54-55. FBI Director Louis Freeh, addressing the House International Relations Committee in 1997, remarked that the future of policing and international relations due to organized crime is in the balance. Freeh remarked that

[b]ecause a substantial portion of FBI cases have some foreign connection, international crime has become one of the most important challenges to face the United States and the law enfocement community. We must act to develop the strategies necessary to address these challenges now and to minimize the impact of international crime on citizens, economy, and national security . . . . Our success is going to be measured by how thoroughly we prepare for what is upon us and how quickly we respond to the emergence of international crime.

Threat, supra note 10, at 54-55. See also Vassalo, supra note 88, at 176. 
in the free-navigation of the sea. ${ }^{181}$ The fundamental character of pirate acts was that they struck "indiscriminately against the vessels and nationals of numerous states"182 and posed a serious threat to interstate commerce and international use of the sea "for military and scientific purposes." 183 Therefore, every nation was given jurisdiction over the acts of pirates because "[s]uch lawlessness was especially harmful to the world at a time when intercourse among states occurred primarily by way of the high seas." 184

Another factor for granting universal jurisdiction over acts of piracy is the fact that a pirate's crime takes place on the high seas, usually outside the jurisdiction of all states. ${ }^{185}$ This created a jurisdictional problem where, based upon traditional principles of international law at the time, no state except the nation for whom the pirate ship flew its flag could punish an act of piracy. Therefore, the jurisdictional problem was overcome by allowing all nations to punish acts of piracy. ${ }^{186}$

Like piracy, criminal enterprises pose a serious international threat to the welfare of the global economy, but in ways that the world has never experienced. ${ }^{187}$ The threat of criminal groups, such as the Russian mafia, become even larger with the materialization of a global economy and the continued growth of new computer and telecommunications technologies. ${ }^{188}$ Racketeering activities performed by criminal enterprises, like acts of piracy, create barriers that limit and threaten the existence of free-markets worldwide.

\section{B. The Move Toward a New International Crime Granting Universal Jurisdiction}

A proactive plan that could be instituted by the United States, Russia, and other world leaders should promote the following: (1) expanding recent American and Russian agreements to cooperate in criminal matters to provide for the prosecution, in United States courts, of criminal enterprises operating between the two countries ${ }^{189}$ and (2) developing and implementing an international treaty among world economic powers that addresses the

181. See Sorensen, supra note 160 , at 226.

182. Randall, supra note 153, at 794.

183. Sorensen, supra note 160 , at 226.

184. Randall, supra note 153 , at 795.

185. See id. at 792.

186. See Sorensen, supra note 160 , at 226.

187. See Threat, supra note 10 , at $49-50$.

188. See Speech, supra note 34.

189. See Agreement on Cooperation in Criminal Law Matters, June 30, 1995, U.S.Russ., 96 U.S.T. 38, available in 1995 WL 831037. See also Speech, supra note 34. 
racketeering activities of criminal organizations by providing universal jurisdiction to all subscribing nations pursuant to principles of international law. These types of actions would promote uncontaminated global markets for those who are involved in world trading while also sanctioning those who do not obey. Addressing the sovereign rights of nations and the foreign policy issues involved must be keenly balanced with the growing problems stemming from transnational organized crime.

\section{Expanding the Cooperation Agreement Between the United States and} Russia as a Vehicle for Prosecution of Criminal Enterprises Operating in Both Countries

In July of 1994, an accord was signed between acting Russian Prosecutor General Illyushenko and FBI Director Louis Freeh, ${ }^{190}$ signaling the beginning of an era of joint law enforcement efforts with the ultimate goal of controlling the Russian mafia. In that same month, the FBI opened a branch office in Moscow with the intent of providing "a police-to-police bridge that will enable Russian and American criminal cases to be fully coordinated, investigated, and supported, here and there."191 Initially, the FBI's main concern was the Russian mafia's ability to gain access to nuclear materials and divert them to hostile nations and parties. ${ }^{192}$ However, the FBI clearly was concerned with the entire spectrum of Russian mafia activities from the outset of its involvement. ${ }^{193}$ It is this "bridge" between Russian and American interests that provides a sufficient tool to begin implementing RICO-type investigations and prosecutions with only the need for an agreement that would allow these types of actions. That type of agreement shortly followed.

In June of 1995, an agreement, a mutual legal assistance treaty (MLAT), between the United States and Russia was signed; ${ }^{194}$ both countries “[noted] the need to unite their efforts and strengthen cooperation between the competent authorities in both countries to prevent and fight against crime." 195 The MLAT expressed that assistance "shall be provided in connection with the investigation, criminal prosecution, and prevention of offenses described in the Annex to this Agreement, and in proceedings

190. See Asnis, supra note 24, at 313.

191. Speech, supra note 34 .

192. See id.

193. See id. Freeh discusses not only the monitoring of nuclear materials diversion, but also touches upon other criminal activities such as drug trafficking, complex tax and health care fraud, and money laundering, to name a few. See id.

194. See Agreement on Cooperation in Criminal Law Matters, June 30, 1995, U.S.Russ., 96 U.S.T. 38, available in 1995 WL 831037.

195. Id. 
related to such criminal matters." 196 The Annex to the MLAT describes the scope of crimes that are to be targeted. ${ }^{197}$ Expressly addressed in provision three of the Annex is "[0]rganized criminal activity and racketeeing, as defined under the laws of the United States of America and the Russian Federation, respectively." 198 This provision of the Annex could be the springboard needed to implement large-scale RICO investigations between the two countries; however, the prosecution of members of criminal enterprises is hindered by the lack of an extradition treaty.

The MLAT does not expressly provide for automatic extradition to a "requesting party" of the agreement; however, it does not forbid it. The "scope of assistance" provision of the agreement includes obtaining several types of evidence, serving documents, executing searches and seizures, locating and identifying persons, and inmobilizing and forfeiting assets. ${ }^{199}$ However, Article II also provides for "any other assistance not prohibited by the laws of the Requested Party." ${ }^{200}$ This provision could imply the existence of extradition rights. Since "criminal prosecutions," an expressed goal of the MLAT, could require parties to be present, extradition is not a far-fetched extension of the spirit of the Agreement. If criminal prosecutions are going to be effective cooperatively, it would seem logical that members of criminal groups would be tried together.

Another option for the United States and Russia is to voluntarily permit extradition of key members of organized criminal groups. The already existing cooperative agreements between the United States and Russia provide the beginning for a movement toward global prosecution and enforcement of laws against organized crime.

\section{Implementation of an International Treaty Providing Prescriptive} Jurisdiction to Subscribing Nations Pursuant to the Universal Principle of International Law

The basic principles behind the right to assert jurisdiction under the universal principle of international law is that "certain offenses are so heinous and so widely condemned that 'any state if it captures the offender may prosecute and punish that person on behalf of the world community regardless of the nationality of the offender or victim or where the crime was committed." 201 Of course, the most controversial aspect of the universal

196. Id. art. 2.

197. See id. annex.

198. Id.

199. See id. art. 2.

200. Id.

201. Covey T. Oliver et al., The International Legal System, Cases and MATERIALS 181 (4th ed. 1995) (quoting M. Bassiouini, II INTERNATIONAL CRIMINAL LAW 
principle is how to classify "heinous." 202 Typically, international conventions and treaties have been the predominant factor in determining whether particular crimes are condemned by the world community and "subject to prosecution under the Universal principal [sic]."203 Examples of offenses that have been "recognized by the community of nations as of universal concern . . . [include] piracy, slave trade, attacks on or hijacking of aircraft, genocide, war crimes, and perhaps certain acts of terrorism." 204

Therefore, nations could implement an international treaty recognizing and condemning international criminal acts conducted by organized criminal groups in furtherance of their organization as heinous to the world community. Such a treaty should focus on a coordinated effort by the subscribing nations and should use a common set of enforcement rules such as the standards and elements necessary for a RICO conviction. ${ }^{205}$ The treaty's focus should be on prosecuting those criminal organizations, or "enterprises," that operate across borders and in world markets, while leaving local "enterprises" to the enforcement mechanisms already in place in their home nations. This type of treaty could grant the authority to better equip nations with more technology, manpower, etc. to assist those states which lack necessary funds and training, thereby giving security to global markets and promoting freedom from racketeering and corruption.

\section{CONCLUSION}

Many world leaders agree that the threat posed by transnational criminal organizations, especially the Russian mafia, which reach beyond the scope of traditional international jurisdiction, is quite substantial and if left unchecked could grow to unprecedented proportions. In fact, it may be too soon a reality that new global criminal groups could be capable of buying entire governments or possibly undermining established western markets. Therefore, the need for new enforcement mechanisms in the struggle against transnational organized crime suggests that world leaders should come together to form alliances that begin to treat racketeering, via criminal

298 (1986)).

202. See id.

203. Id. However, it must be remembered that other means for providing evidence that a criminal offense is subject to the universal principle is by custom and tradition.

204. Id. at 178 (emphasis in original).

205. See supra Part III. 
enterprises, as universally condemnable. Serving as a model of success, the United States' RICO Act demonstrates that powerful legislation, supported by aggressive enforcement, can limit criminal enterprises substantially.

Larry D. Newman*

* J.D. Candidate, 1999, Indiana University School of Law - Indianapolis; B.A., 1993, University of Northern Iowa. The author would like to extend special thanks to his wife, Margaret, for her encouragement and support. 
